\title{
Evaluation of the Hydrocarbon Maturity Level of Oil Well in Sedimentary Basin of the Northern Niger Delta, Nigeria.
}

\author{
EMUJAKPORUE, G. O.; EKINE, A. S.; NWANKWO, C. N. \\ Department of Physics, University of Port Harcourt, Port Harcourt, Nigeria E-mail: owin2009@yahoo.com
}

\begin{abstract}
The hydrocarbon maturation level of Oben-1 well in the northern Niger Delta sedimentary basin was evaluated using the Lopatin "Time- Temperature Index (TTI). The result shows that sediments in the basin are both oil and gas producing with the oil window lying between the depths of 2.5 to $3.5 \mathrm{~km}$. Time of hydrocarbon generation varies from 36 Ma upwards. The hydrocarbon maturation level was estimated for seven horizons (A, B, C, $\mathrm{D}, \mathrm{E}, \mathrm{F}$ and $\mathrm{G}$ ), and the results show that horizons $\mathrm{A}, \mathrm{B}, \mathrm{C}$ and $\mathrm{D}$ which are less than $36 \mathrm{Ma}$ are non oil and gas producing (i.e. TTI $<15$ ) while horizons $\mathrm{E}, \mathrm{F}$ and $\mathrm{G}$ which are more than $36 \mathrm{Ma}$ old are both oil and gas producing. This result is in agreement with the values of Vitrinite reflectance obtained for the well. This study shows that exploratory wells in the area should be extended beyond the depth of 3.5 kilometres and that the hydrocarbon prospects of the northern Niger Delta is high. @ JASEM
\end{abstract}

The Niger Delta sedimentary basin is a major petroleum province for oil and gas. Intensive petroleum exploration and exploitation activities in the Delta region during the last four decades have led to the accumulation of a vast amount of data from which it has been possible to establish the hydrocarbon habitat and to reconstruct the history and evolution of the Niger Delta basin (Ekweozor and Daukoru, 1994; Emujakporue, 2009; Doust and Omatsola, 1990; Stacher, 1995; Kulke, 1995; Klett et al., 1997). Measured maturity values for possible source rocks are invaluable because they tell us much about the present status of hydrocarbon generation at the sample location. It has been generally established in recent years that both time and temperature are important factors in the process of oil generation and in the cracking of oil to gas (Marchard at al, 2002; Abu and Mohamed, 2008). Several techniques have been developed to quantify the relationship between temperature and time to kerogen maturity. Two commonly used maturation indices are the time temperature index (TTI) and the Level of Organic Maturation (LOM). The TTI method was first proposed by Lopatin (Nordeng, 2008) and developed by Waples et al., (1992). The thermal maturity index is calculated from a formula which integrates temperature with the time spent in each temperature interval (in increments of $10^{\circ} \mathrm{C}$ ) as a source rock is buried. Secondly, the LOM which was first proposed by Hood et al., (1975) and developed by Royden et al.,(1980), in (Nwankwo, 2007), is based on the assumption that reaction rate doubles for each $10^{\circ} \mathrm{C}$ increment of temperature. Both the TTI and LOM techniques assumed that geothermal gradient is constant through time. In this work, we have tried to carry out evaluation of the hydrocarbon maturity level of an oil exploratory well (Oben-1) in the northern Niger Delta sedimentary basin (Fig. 1).

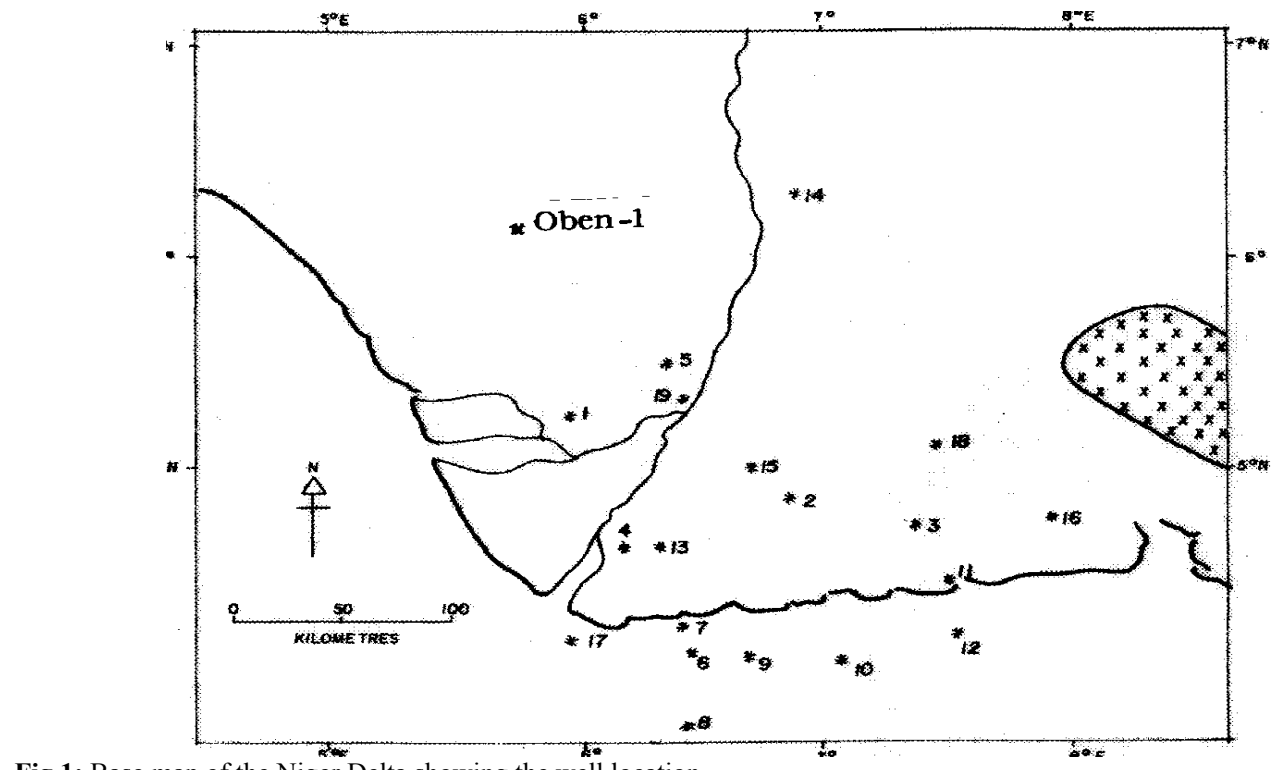

Fig.1: Base map of the Niger Delta showing the well location. 
GEOLOGY OF THE NIGER DELTA

The Niger Delta is the youngest sedimentary basin within the Benue Trough system. The Niger delta development began after the Eocene tectonic phase. Up to $12 \mathrm{~km}$ of deltaic and shallow marine sediments have been accumulated in the basin. The Niger and Benue Rivers are the main supplier of sediments. Three lithostratigraphic units are distinguishable in the Tertiary Niger Delta. The basal Akata Formation which is predominantly marine prodelta shale is overlain by the paralic sand/shale sequence of the Agbada Formation. The topmost section is the continental upper deltaic plain sands - the Benin Formation. Virtually all the hydrocarbon accumulations in the Niger Delta occur in the sands and sandstones of Agbada Formation where they are trapped by rollover anticlines related to growth fault development (Ekweozor and Daukoru, 1994; Michele et al., 1999; Uko, 1996).

\section{MATERIALS AND METHODS}

The basic data for this work are the burial history chart of the Northern portion of the Niger Delta modified from Ekweozor and Daukoru (Michele et al., 1999), botton hole temperature of Oben-1 well and the geothermal gradient of the Western Niger Delta obtained from Ogagarue (1998). Implementation of the Lopatin's method begins with a reconstruction of the depositional and tectonic history of the geologic section of interest. This was best accomplished by plotting depth of burial versus geological age and to specify its temperature history. The basic equation for the computation is given as

$T T I=\sum_{n_{\min }}^{n_{\max }}\left(\Delta T_{n}\right)\left(r^{n}\right)$

where $\Delta \mathrm{T}_{\mathrm{i}}=$ length of time in millions of years spent by the sediment in the temperature interval; $\mathrm{n}_{\max }$ and $\mathrm{n}_{\min }$ are the $\mathrm{n}$ - values of the highest and lowest temperature interval encountered; $r=2$.

The second aspect of the geologic model is the temperature-history. Subsurface temperature was specified for every depth throughout the relevant geologic past. This was done by computing the present geothermal gradient $\left(31^{\circ} \mathrm{C} / \mathrm{Km}\right.$, Ogagarue, 1998) measured from continuous temperature $\log$ of Oben-1 well in the northern Niger Delta. It was assumed that both the gradient and surface temperature (i.e $27^{\circ} \mathrm{C}$, Uko, 1996) has remained constant through the geologic history. After the burial-history curves and temperature grids have been constructed, they were then superimposed. The intersection of the burial history curve with each isotherm was then marked out. These points of intersection define the time and temperature intervals that were used in the calculation.

\section{RESULTS AND DISCUSSION}

The burial history and the reconstructed temperature grid with equally spaced isotherms of Oben-1 well in the northern Niger Delta are shown in Figures 2 and 3 respectively. The superimposed chart of the burial history and the temperature grid is shown in Figure 4. Total maturity was calculated using equation 1 , where the time factors and the two (2) factors for each temperature intervals are shown on the burial curve. The calculated-total TTI values for each horizon are shown in Table 1.

Table1. Summary of TTI Calculation for Geologic Horizons in the Northern Niger Delta.

\begin{tabular}{lc}
\hline HORIZON & TOTAL TTI \\
\hline A & $0.0078-0.1478$ \\
B & $0.0098-1.0918$ \\
C & $0.0039-4.992$ \\
D & $0.0019-14.52$ \\
E & $0.0020-123.749$ \\
F & $0.00039-594.84$ \\
\hline G & $0.002-22,576$ \\
\hline
\end{tabular}

* Corresponding author: Emujakporue, G. O. 


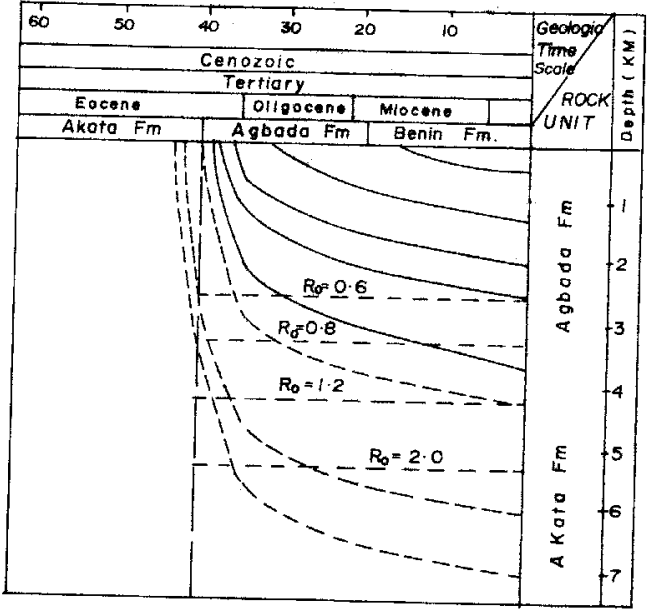

Fig. 2: Burial history chart for the Northern portion of the Niger Delto (Akato / Agbodo petroleum system. Data from Oben I

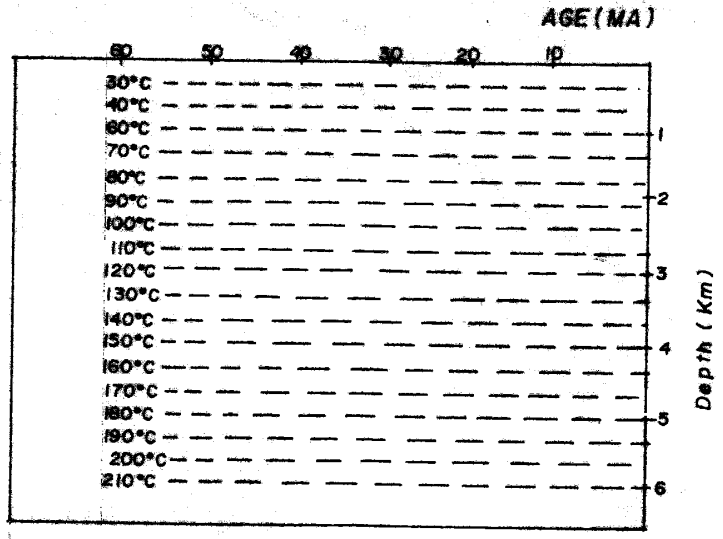

Fig. 3: Subsurfoce - temperoture grid that assumes a constont surface femperoture $\left(27^{\circ} \mathrm{C}\right)$ and geothermal gradient $\left(31^{\circ} \mathrm{C} / \mathrm{Km}\right)$ during the lost $50 \mathrm{my}$. Isotherms ore space every $10^{\circ} \mathrm{C}$ for convenience in calculating hydrocorbon moturity.

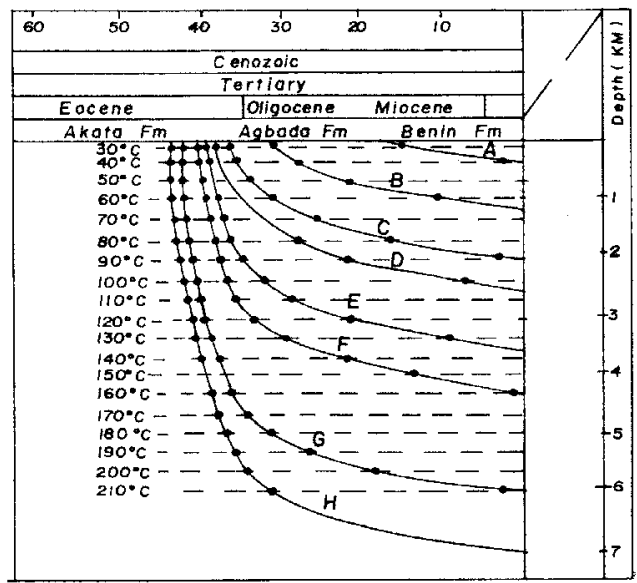

Fig. 4: Time/temperoture/depth plot for Oben 1 in the Northern Niger Delto

The geohistory analysis of the data from Oben-1 well shows that the simple cooling model for oceanic lithosphere explains the subsidence of the basin. The results of the analysis show that the delta proper began developing in the Eocene. The sediments that have accumulated in the basin now are over $8.0 \mathrm{~km}$ thick. The paleotemperature profiles of the sedimentary horizons in the Oben-1 well have revealed the duration and extent of heating to which the sediments have been subjected. This has provided an insight into the level of the maturation of the organic matter contained in the sediments.

The result of the hydrocarbon maturation modeling for the six Horizons (A, B, C, D, E, F and G) shows that horizon A, B, C, and D are immature (i.e. TTI < 15). These horizons are less than 36MA old (Oligocene to present). Horizons E, F and G are mature and are both oil and gas generating horizons.
Horizon F contains oil with API gravity $<40$ (i.e. TTI $=500$ ), while horizon $\mathrm{G}$ is wet gas producing (i.e. TTI > 1500). These horizons are between 36 and $40 \mathrm{MA}$ old. The result shows that the oil window lies between the depths of $2.5 \mathrm{~km}$ to $3.5 \mathrm{~km}$. Comparism of the estimated TTI values with the vitrinite reflectances values which accompany the burial history shows that the TTI values are reliable. The vitrinite reflectance values show that the oil window ranges from $2.4 \mathrm{~km}$ to $3.3 \mathrm{~km}$ and that the well is both oil and gas producing.

Conclusion: A general picture of the hydrocarbon maturity and generation histories of the study area has been developed using the Lopatin's "timetemperature" maturity index. One of the advantages of the method is that the required input data are very simple and easy to obtain. The results of the analysis 
show that horizons which are more than $36 \mathrm{Ma}$ old are both oil and gas producing (i.e. TTI $>15$ ) while those horizons that are less than $36 \mathrm{Ma}$ old are immature (i.e. TTI $<15$ ). The predictive ability and accuracy of the Lopatin's model in hydrocarbon generation modeling depends largely on the accuracies in time and available temperature data. In actuality, time data are seldom a problem. However, temperature is the most important cause of uncertainty and error in maturity calculations. The quantitative estimations of the hydrocarbon maturity indicate that significant volumes of hydrocarbons were generated by the source rocks and most of them are yet unexplored. Petroleum generation within the delta began in the Eocene and is continuous presently. It is therefore hoped that the hydrocarbon maturity values presented herein will provide some incentives for drilling in areas still unexplored and will encourage the testing of deeper drilling prospects in the study area.

\section{REFERENCE}

Abu, B F M; Mohamed, R M R (2008). Nature of organic matter, thermal maturation and hydrocarbon potentiality of Khatatba Formation at East Abu- gharadig basin, northwestern desert, Egypt. Australian. Jour. Basic and Applied Sc., 2(\#2): 194-209.

Doust, H; Omatsola, E M (1990). The Niger Delta in Divergent/passive margin Basins ed. T.O Edwards and P.A Santugross, A. A. P. G. Memoirs 45: 201 - 238.

Ekweozor, C M; Daukoru, E M (1994). Northern delta depobelt portion of the Akata- Agbada. (1) Petroleum system, Niger Delta, Nigeria, In, Magom, L.B., and Dow, W.G., eds. The petroleum system- from source to Trap, A. A. P. G. Memoir 60: Tulsa, $599-614$.

Emujakporue, O G (2009). Subsidence and geothermal history in the eastern Niger delta with implications for hydrocarbons. Unpublished $\mathrm{Ph}$. D. Thesis, University of PortHarcourt, PortHarcourt.
Klett, T R; Ahlbrandt, T S; Schmoker, J W; Dolton, J L (1997). Ranking of the Worlds oil and Gas provinces by known petroleum volumes. E.S. Geological survey, Open-file. Report -97-463, $\mathrm{CD}=\mathrm{ROM}$.

Kulke, H. (1995). Nigeria, In, Kulke, H., ed. Regional Petroleum Geology of the World part 11: African, America, Australia and Antarctica: Berlin, Gebruder. Bornbraeger, 143 - 172.

Marchard, F M A; Smalley, C P; Haszcldine, S R; Fallick, A F ( 2002). Note on the importance of hydrocarbon fill for reservoir quality prediction in sandstones. A. A. P. G. Bull., 86(9): 1561 1571.

Michele, L W T; Ronald, R C; Michael, E B (1999). The Niger delta petroleum system: Niger delta province, Nigeria, Cameroon, and Equatorial Guinea, Africa. Open-file report 99-50-H.

Nordeng, H S (2008). Time- temperature index of Bakken formation in the North Dakota. North Dakota geological survey, geologic investigation, no. 61 .

Nwankwo, C N (2007). Heat flow studies and hydrocarbon maturation modeling in the Chad basin, Nigeria. Unpublished Ph. D. Thesis, University of PortHarcourt, PortHarcourt.

Ogagarue, D O (1998). Heat flow estimate in western Niger Delta sedimentary basin. Unpublished M. Sc. Thesis, University of PortHarcourt, PortHarcourt.

Stacher, P (1995). Present understanding of the Niger Delta hydrocarbon habitat, in: Oti, M.N. and Postma, G. eds. Geology of Deltas; Frotterdam A.A., Bakkema, 57 - 267.

Uko, E D (1996). Thermal modeling of the Northern Niger delta. Unpublished Ph. D. Thesis, Rivers State University of Science and Technology, PortHarcourt.

Waples, D W; Suizu, M; Mamata, H (1992). The art of maturity modeling. Part 1. Finding a satisfactory geologic model. A. A. P. G. Bull., 76: $31-46$. 